\title{
Nutrient Digestibility and Growth of Five Breeds of Sheep under Different Levels of Undegradable Protein
}

\author{
Yulistiani $\mathrm{D}^{1}$, Naufaliah $\mathrm{N}^{2}$, Kardaya $\mathrm{D}^{2}$, Subandriyo ${ }^{1}$ \\ ${ }^{1}$ Balai Penelitian Ternak, PO Box 221, Bogor 16002 \\ ${ }^{2}$ Universitas Djuanda, Jl. Tol Ciawi 1 Kotak Pos 35, Ciawi-Bogor 16720 \\ E-mail: dwiyulistiani@yahoo.com
}

(Diterima 2 Februari 2015; direvisi 9 Maret 2015; disetujui 20 Maret 2015)

\begin{abstract}
ABSTRAK
Yulistiani D, Naufaliah N, Kardaya D, Subandriyo. 2015. Kecernaan nutrisi dan pertumbuhan lima rumpun domba pada beberapa tingkat kandungan protein tidak terdegradasi. JITV 20(1): 23-30. DOI: http://dx.doi.org/10.14334/jitv.v20i1.1112

Penelitian dilakukan dengan tujuan untuk mengevaluasi pengaruh pemberian pakan konsentrat yang mengandung dua tingkat protein yang tidak terdegradasi di dalam rumen terhadap tampilan lima bangsa domba yaitu: Compass Agrinak (CA), Komposit Garut (KG), persilangan Barbados (BC), St. Croix (SC) dan Garut local (GL). Digunakan 10 ekor domba yang dikelompokkan menjadi lima kelompok berdasarkan bobot badan dan masing-masing kelompok diacak untuk mendapatkan salah satu dari dua level UDP pada pakan konsentrat yang diujikan. Dua level kandungan UDP dalam konsentrat yang diujikan adalah 4,5 dan 7,5\%. Pakan konsentrat diformulasikan secara iso protein dan iso energy dengan kandungan protein kasar 16,7\% dan energy metabolis $2,5 \mathrm{Mcal} / \mathrm{kg}$. Domba ditempatkan pada kandang individu selama tiga bulan pengamatan, dengan menggunakan rancangan acak kelompok pola faktorial 5 x 2, yaitu 5 level bangsa domba dan 2 level kandungan UDP. Hasil penelitian menunjukkan tidak adanya interaksi antara bangsa domba dan tingkat UDP terhadap konsumsi pakan, pertambahan bobot badan harian, konversi pakan dan kecernaan nutrisi pakan. Variabel tersebut nyata $(\mathrm{P}<0,05)$ dipengaruhi oleh perbedaan bangsa domba. Konsumsi pakan, protein, energi dan pertambahan bobot badan harian (PBBH) tertinggi pada domba KG. Namun demikian PBBH domba KG tidak berbeda nyata dengan domba GL. Kecernaan nutrisi pakan tidak dipengaruhi $(\mathrm{P}>0,05)$ oleh interaksi antara faktor bangsa domba maupun oleh kandungan UDP, kecuali pada kecernaan bahan organik. Di lain pihak, bangsa domba tidak mempengaruhi kecernaan nutrient pakan, sedangkan tingkat UDP hanya mempengaruhi kecernaan serat deterjen netral (SDN). Dari hasil penelitian ini dapat disimpulkan bahwa peningkatan kadar UDP dalam pakan konsentrat tidak meningkatkan pertumbuhan domba. Dengan pemberian pakan yang berkualitas sama, pertumbuhan domba dipengaruhi oleh bangsa domba, dimana KG dan GL mempunyai pertumbuhan yang sama (86,01 vs 82,38 g/hari).
\end{abstract}

Kata Kunci: Bangsa Domba, Pertumbuhan, Protein Tidak Terdegradasi, Kecernaan

\section{ABSTRACT}

Yulistiani D, Naufaliah N, Kardaya D, Subandriyo. 2015. Nutrient digestibility and growth of five breeds of sheep under different levels of undegradable protein. JITV 20(1): 23-30. DOI: http://dx.doi.org/10.14334/jitv.v20i1.1112

A study was conducted to evaluate the effect of feeding different levels of rumen undegradable protein (UDP) in concentrate on performance of five breeds of sheep. Namely: Compass Agrinak (CA); Garut Composite breed (KG); Barbados Cross breed (BC); St Croix breed (SC); and Local Garut (GL) breed. Ten heads of sheep were used from each breed, in which each breed was grouped into 5 groups according to their body weight, and each sheep in each group was assigned to one of two treatments diet. The diet treatment consisted of concentrate containing different levels of undegradable protein (UDP). The levels of undegradable protein were $4.5 \%$ and $7.5 \%$. Concentrate were formulated in iso nitrogen (CP content 16.7\%) and iso energy (ME content $2.5 \mathrm{Mcal} / \mathrm{kg}$ ). During feeding trial the sheep were kept in individual pen for three months. Study was conducted in randomized complete block design in factorial 5 x 2 arrangement, 5 levels of breeds sheep and 2 levels of UDP content. Results shows that there was no interaction effect of breed and levels UDP on feed consumption, average daily gain and feed conversion. These variables were significantly $(\mathrm{P}<0.05)$ affected by breed of sheep. The highest DMI (dry matter intake) was in KG sheep, the highest DMI caused by highest crude protein and gross energy intake, which in turn lead to highest average daily gain (ADG) of this breed. However the ADG of KG was not significantly different from GL. Apparent nutrient digestibility was not affected $(\mathrm{P}>0.05)$ by interaction between breed of sheep and UDP levels in the diet except for OM digestibility. While breed of sheep did not affect nutrient digestibility and UDP levels only affected NDF digestibility. From this study, it is concluded that increasing UDP in the diet did not improve growth performance of sheep. At similar quality of feed the growth performance was affected by breed of sheep in which KG and GL sheep had similar average daily gain (86.01 vs $82.38 \mathrm{~g} /$ day).

Key Words: Breed of Sheep, Undegradable Protein, Growth, Digestibility 


\section{INTRODUCTION}

Protein forms are the most important components in ruminants' ration, therefore it is crucial to ensure that this nutrients could be utilize efficiently. Protein requirement of ruminants can be supplied from microbial protein synthesis and dietary protein that escapes from microbial degradation in the rumen (rumen undegradable protein/UDP) and reaches the small intestine for digestion and absorption. For high production state of ruminants such as at growing and lactating their protein requirement can not be met only from microbial protein synthesis. To support high rates of production, they must be supplied with UDP. Providing ration to animals containing UDP will provide addition protein to microbial protein for tissue deposition as well nitrogen source for endogenous recycling (Atkinson et al. 2007). However, due to the most of fibrous diet in ruminants are fermented in the rumen, part of the protein supplied in diet should be fermentable in the rumen to meet the nitrogen requirement of rumen microbial. So that able to support microbial growth which in turn increase fiber digestion in the rumen. Therefore supplying protein in diet containing balanced between rumen degradable protein (RDP) and rumen undegradable protein (UDP) should be considered (Garg 1998). McDonald et al. (2002) suggested that for maintenance and growth of sheep, the RDP requirement was about $60 \%$ of total protein in the diet.

The productivity of livestock affected by genetic and environmental factor such as diet. The higher productivity breed usually followed by higher nutrient requirement such as protein which is needed for tissue deposition. Inounu et al. (2003) reported that Garut composite breed had higher body weight at 12 months of age than local garut breed sheep in better feeding management. Similarly Yulistiani et al. (2014) reported that at village feeding management system and under stress condition, among four breeds of sheep, Garut composite breed had bttter response to the better feed management. On the other hand Compass agrinak breed, Barbados cross breed and local Garut sheep had lower growth rate and responded similarly to diet either un-supplemented or supplemented native grass basal diet. Subandriyo et al. (2000) also reported that Compass agrinak breed and Barbados cross breed (as contemporary breed to Compass agrinak breed) had similar performance in trait of growth and dam productivity. It shows that from previous study, different breed had different response to different diet which might be caused by different nutrient requirement. So far, limited information on response of growth and digestibility of five breed of sheep fed on similar diet quality particularly in different content of rumen undegradable protein (UDP). Therefore the objective of this study was to evaluate the growth and nutrient digestibility of five breed of sheep fed on diet containing defferent levels of UDP.

\section{MATERIALS AND METHODS}

\section{Animals dietary treatments and experimental design}

The study used 50 heads of sheep from 5 breeds namely: Barbados Black Belly Cross (BC) (genetic composition $50 \%$ Local Sumatera $50 \%$ Barbados Black Belly), Garut Composite (KG) (50\% Local Garut 25\% St. Croix 25\% Moulton Charolais), Compass Agrinak (CA) $(50 \%$ Local Sumatera $25 \%$ St. Croix $25 \%$ Barbados Black Belly), St. Croix (SC), and local Garut sheep (GL). The average body weight of sheep used in this experiment were $21.01 \pm 3.24 \mathrm{~kg}$ at age 11 months old. The animals in each breed were divided into two groups of diet treatments in a completely randomized block design and were placed in individual pen during growth trials.

The sheep were fed on fresh chopped elephant grass containing 6.56\% Crude protein, 69.59\% NDF, 1.7037 Mcal ME/kg was offered daily for ad libitum consumption. Supplements as diet treatment was offered at $450 \mathrm{gr} \mathrm{DM} /$ day, were formulated to contain iso energetic (2.5 Mcal ME/kg DM) and iso protein (16.7\%) which contained two different levels of UDP (4.5 and $7.5 \%$ ), and used as diet treatments. The $4.5 \%$ UDP treatment supplied $60 \%$ of rumen degradable protein (RDP), while $7.5 \%$ UDP treatment supplied $50 \%$ RDP. The composition and chemical analysis of the supplements presented in Table 1. The UDP source was obtained from feed ingredients (coconut meal, rice bran, ground corn, soy bean meal, fish meal) used in formulating concentrate diet. The proportion UDP content of each feed was obtained from Mc Donald et al. (2002), after these feeds were analysed for its crude protein content. Drinking water was freely available to the animals. All the sheep were dewormed using Valbazen at the beginning of the experiment. Growth Trial was conducted for 14 weeks including 2 weeks for adaptation periods. During growth trial sheep were weighed weekly, feed offered and refusal were recorded daily prior to morning feeding.

Study was conducted in completely randomized block design in $2 \times 5$ factorial arrangement, the first factor was two UDP levels (4.5 and 7.5\%) and the second factor was five breeds of sheep. 
Table 1. Ingredient and chemical composition of concentrate feed

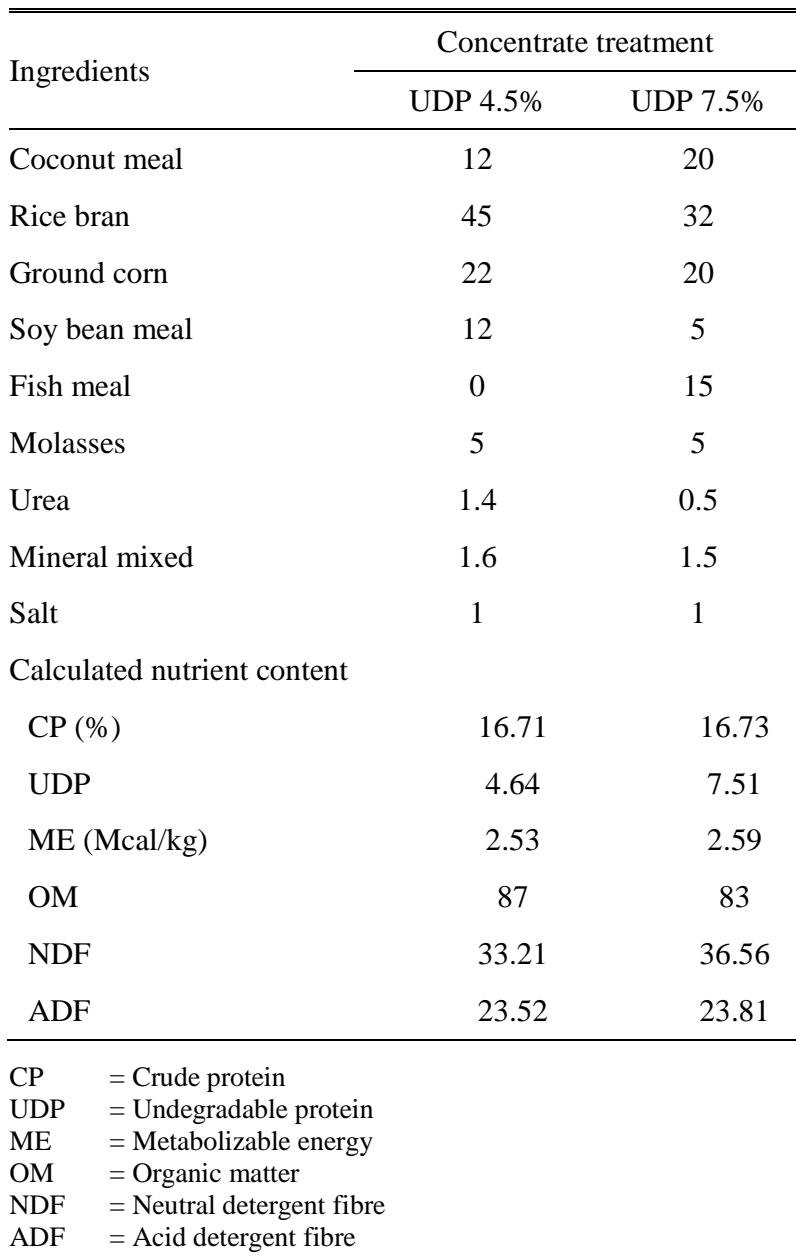

\section{Digestibility trial}

At the end of growth trial sheep were moved to metabolic crates for a digestibility trials. The digestibility trial consisted of 3 days of adaptation period and 7 days for sample collection. During the collection period daily feed intake and refusal and fecal output of the individual sheep were recorded. Daily grab samples of forage and orts were collected. Daily fecal output was collected and recorded from individual sheep before their morning feeding. Each representative portion of fecal sample (10\% from total fecal output) was oven-dried at $60^{\circ} \mathrm{C}$ for $48 \mathrm{~h}$. At the end of the collection period, the feces were pooled for individual sheep and a $10 \%$ sub-sample were ground through $1 \mathrm{~mm}$ sieve and stored pending for chemical analyses.

\section{Chemical analyses}

Feeds, residues and feces were analyzed for DM, $\mathrm{OM}$, and $\mathrm{CP}$ contents according to the procedures of AOAC (1990). The fiber component (NDF and ADF) were determined according to the procedures of Van Soest et al. (1991).

\section{Statistical analyses}

Data were analyzed by ANOVA for completely randomized block design in factorial 2 x 5 using General Linear Model procedure (GLM) of SAS 9.2 (2009). Differences among treatment means were detected using Duncan's multiple range tests. Significance was taken at $\mathrm{P}<0.05$.

\section{RESULTS}

The concentrates were intended to contain UDP 4.5 for diet 1 and $7.5 \%$ for diet 2 , however, after diet was formulated the contained of UDP in $4.5 \%$ became 4.64\% whereas UDP $7.5 \%$ became $7.51 \%$ (Table 1). Interaction between breeds and UDP levels were not observed in total DMI, DMI/BW, DMI/BW ${ }^{0.75}$. Therefore only the main effects are presented in Table 2. Total DMI, DMI/BW, DMI/BM were significantly affected by breeds of sheep but not by UDP levels. DMI of KG was significantly higher than other breeds but was not significantly different to $\mathrm{BC}$, while the lowest DMI was in GL. However, when the intake was converted into intake per body weight (DMI/BW) and intake per metabolic body weight $\mathrm{DMI} / \mathrm{BB}^{0.75}$ ) the highest total intake was in GL but was not significantly different to $\mathrm{SC}$ and $\mathrm{KG}$.

Interaction between breeds and UDP levels were not observed in initial body weight, final body weight, average daily gain (ADG) and feed conversion. Therefore only the main effects are presented in Table 3. Table 3 shows the initial body weight of the sheep was significantly affected $(\mathrm{P}<0.05)$ by breeds but was not affected $(\mathrm{P}>0.05)$ by diets treatment. After 12 weeks of experiment the final body was still affected by breed. Similar to body weight, the ADG was also affected by breed factor. The levels of UDP in the diet did not affect ADG. The highest ADG was in KG but it was not significantly different to GL. Feed conversion was affected $(\mathrm{P}<0.05)$ by breeds but not by diet treatments. KG and GL sheep had similar feed conversion than BC and $\mathrm{CA}$ but was not significantly different to SC. 
Table 2. Intake of dietary dry matter, protein and energy of five breeds of sheep

\begin{tabular}{|c|c|c|c|c|c|c|c|}
\hline \multirow[b]{2}{*}{ Factors } & \multicolumn{7}{|c|}{ Parameter } \\
\hline & $\begin{array}{c}\text { DMI } \\
\text { (g/day) }\end{array}$ & $\begin{array}{l}\mathrm{DMI} / \mathrm{B} \\
\mathrm{W}(\%)\end{array}$ & $\begin{array}{c}\mathrm{DMI} / \mathrm{MBW} \\
\left(\mathrm{g} / \mathrm{kg} \mathrm{BB}^{0.75}\right)\end{array}$ & $\begin{array}{c}\text { CP I } \\
\text { (g/day) }\end{array}$ & $\begin{array}{c}\text { CP I } \\
\text { (g/kg BW) }\end{array}$ & $\begin{array}{l}\text { GE intake } \\
\text { (Kcal/day) }\end{array}$ & $\begin{array}{c}\text { GE intake } \\
\text { (Kcal/kg BW) }\end{array}$ \\
\hline Breeds & $* *$ & $* *$ & $* *$ & $* *$ & $* *$ & $* *$ & $* *$ \\
\hline $\mathrm{BC}$ & $906.0^{\mathrm{ab}}$ & $3.26^{\mathrm{d}}$ & $74.77^{\mathrm{c}}$ & $107.34^{\mathrm{ab}}$ & $3.86^{\mathrm{d}}$ & $3542.84^{\mathrm{ab}}$ & $127.28^{\mathrm{d}}$ \\
\hline $\mathrm{SC}$ & $882.6^{\mathrm{b}}$ & $3.7^{\mathrm{ab}}$ & $81.66^{\mathrm{a}}$ & $106.73^{b}$ & $4.49^{\mathrm{b}}$ & $3440.92^{\mathrm{b}}$ & $144.17^{\mathrm{ab}}$ \\
\hline $\mathrm{CA}$ & $881.9^{b}$ & $3.41^{\mathrm{cd}}$ & $76.8 b^{c}$ & $106.50^{\mathrm{b}}$ & $4.12^{\mathrm{bc}}$ & $3438.1^{\mathrm{b}}$ & $132.73^{\mathrm{cd}}$ \\
\hline KG & $938.4^{\mathrm{a}}$ & $3.55^{\mathrm{bc}}$ & $80.4^{\mathrm{ab}}$ & $108.03^{\mathrm{a}}$ & $4.10^{c}$ & $3667.56^{\mathrm{a}}$ & $138.82^{\mathrm{bc}}$ \\
\hline GL & $823.2^{c}$ & $3.84^{\mathrm{a}}$ & $82.50^{\mathrm{a}}$ & $105.29^{c}$ & $4.92^{\mathrm{a}}$ & $3218.32^{c}$ & $149.78^{a}$ \\
\hline UDP levels & n.s & n.s & n.s & $* *$ & $*$ & $* *$ & $* *$ \\
\hline 4.5 & 875.8 & 3.60 & 80.13 & $109.73^{\mathrm{a}}$ & $4.44^{\mathrm{a}}$ & $3551.74^{\mathrm{a}}$ & $142.82^{\mathrm{a}}$ \\
\hline 7.5 & 892.5 & 3.51 & 78.30 & $103.83^{\mathrm{b}}$ & $4.16^{\mathrm{b}}$ & $3371.38^{\mathrm{b}}$ & $134.27^{\mathrm{b}}$ \\
\hline SEM & 23.7267 & 0.1315 & 2.20886 & 0.2262 & 0.07753 & 35.4288 & 2.0684 \\
\hline
\end{tabular}

$* *=\mathrm{P} \leq 0.01 ; *=\mathrm{P} \leq 0.05 ; \mathrm{n} . \mathrm{s}=\mathrm{P} \geq 0.05$

Means followed by different letter in the same column indicate significantly different at $5 \%$

$\mathrm{BC}=$ Barbados Black Belly Cross $\quad \mathrm{KG}=$ Garut Composite

$\mathrm{GL}=$ Local Garut $\quad$ UDP= Undegradable protein

$\mathrm{BW}=$ Body weight $\quad$ MBW $=$ Metabolic body weight

$\mathrm{CA}=$ Compass Agrinak;

$\mathrm{MBW}=$ Metabolic body weight $\quad$ CPI = Crude protein intake

$\mathrm{GE}=$ Gross energy

Table 3. Initial and final weight, average daily gain and feed conversion ratio of five breed of sheep fed on supplements containing different UDP

\begin{tabular}{lcccc}
\hline \hline \multirow{2}{*}{ Factors } & \multicolumn{3}{c}{ Parameter } \\
\cline { 2 - 5 } & Initial BW $(\mathrm{kg})$ & Final BW $(\mathrm{kg})$ & ADG $(\mathrm{g} /$ day $)$ & Feed conversion \\
\hline Breeds & $* *$ & $* *$ & $* *$ & $*$ \\
BC & $24.04 \mathrm{a}$ & $31.71 \mathrm{bc}$ & $68.69 \mathrm{~cd}$ & $14.40 \mathrm{a}$ \\
SC & $20.14 \mathrm{~b}$ & $27.62 \mathrm{~cd}$ & $72.86 \mathrm{bc}$ & $11.43 \mathrm{ab}$ \\
CA & $22.38 \mathrm{ab}$ & $28.82 \mathrm{bc}$ & $57.14 \mathrm{~d}$ & $13.62 \mathrm{a}$ \\
KG & $21.67 \mathrm{~b}$ & $31.1 \mathrm{ab}$ & $86.01 \mathrm{a}$ & $10.56 \mathrm{~b}$ \\
GL & $17.1 \mathrm{c}$ & $25.56 \mathrm{~d}$ & $82.38 \mathrm{ab}$ & $10.00 \mathrm{~b}$ \\
UDP levels & $\mathrm{n} . \mathrm{s}$ & $\mathrm{n} . \mathrm{s}$ & n.s & n.s \\
4.5 & 21.07 & 29.02 & 72.67 & 13.10 \\
7.5 & 20.97 & 28.73 & 73.81 & 12.20 \\
SEM & 0.4757 & 0.5110 & 6.3229 & 1.4875 \\
\hline
\end{tabular}

$* *=\mathrm{P} \leq 0.01 ; *=\mathrm{P} \leq 0.05 ; \mathrm{n} . \mathrm{s}=\mathrm{P} \geq 0.05$

Means followed by different letter in the same column indicate significantly different at $5 \%$

$\mathrm{BC}=$ Barbados Black Belly Cross

$\mathrm{KG}=$ Garut Composite

$\mathrm{CA}=$ Compass Agrinak

$\mathrm{SC}=$ St. Croix

GL = Local sheep breed (Local Garut)

$\mathrm{ADG}=$ Average daily gain

$\mathrm{UDP}=$ Undegradable protein

Growth pattern of sheep during experiment shows that the sheep still in growth stage as shown in Figure 1. Apparent nutrients digestibility in sheep fed the different supplements are given in Table 4 . There were no significant $(\mathrm{P}>0.05)$ interaction between breeds and UDP levels in DM, CP, NDF, ADF and energy digestibility. Therefore, the data of main effect are presented in Table 4. Digestibility of DM, CP, NDF, ADF and energy was not significantly $(\mathrm{P}>0.05)$ affected neither by breeds nor by UDP levels. The nutrients digestibility was similar across the breeds and between the UDP levels. BC: Barbados Black Belly Cross; KG: Garut Composite; CA/KS: Compass Agrinak; SC: St. Croix GL: local sheep breed (Local Garut); UDP: undegradable protein.

Apparent digestibility of $\mathrm{OM}$, on the other hand, was significantly $(\mathrm{P}<0.05)$ affected by interaction between breeds and UDP levels, the data presented in Table 5. The digestibility of OM at UDP $4.5 \%$ in SC and $\mathrm{CA}$ was only significantly higher than $\mathrm{KG}$, but was 


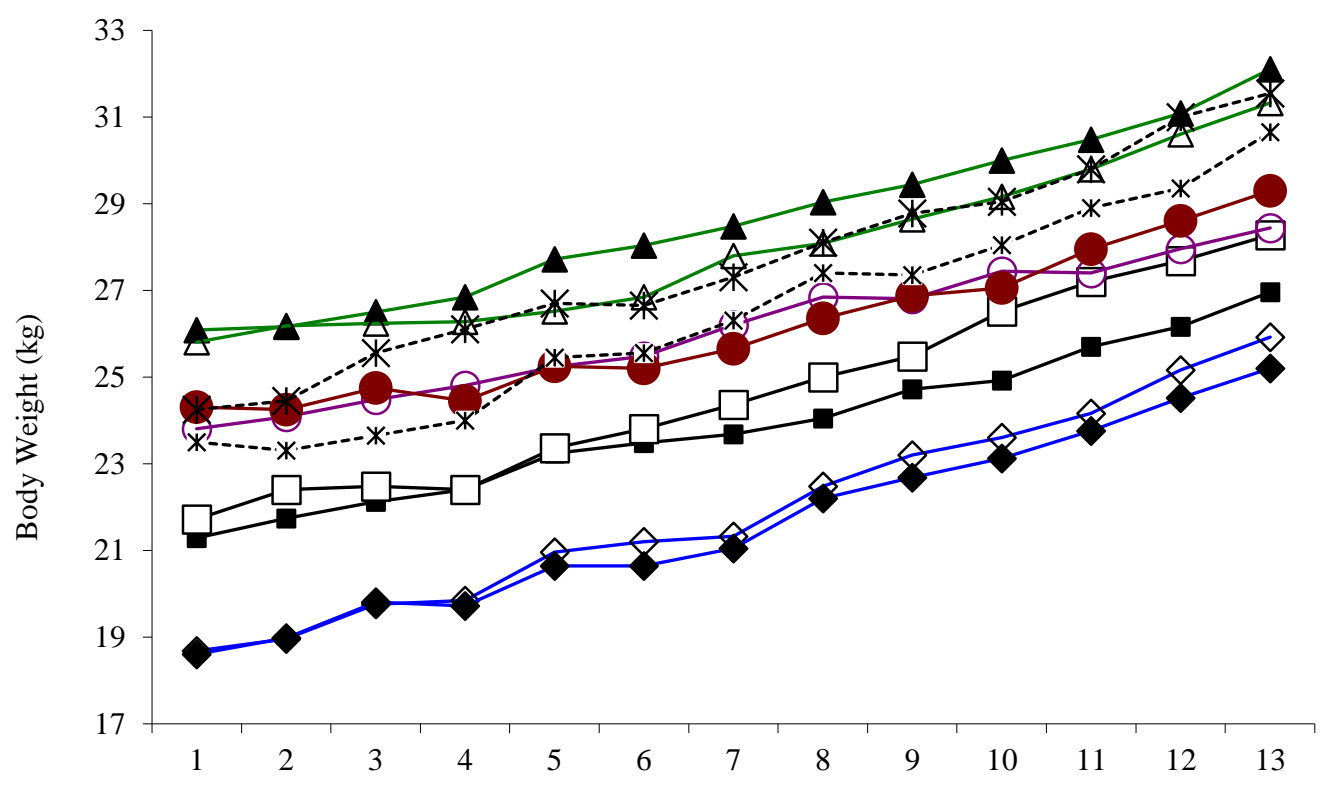

Time (week)

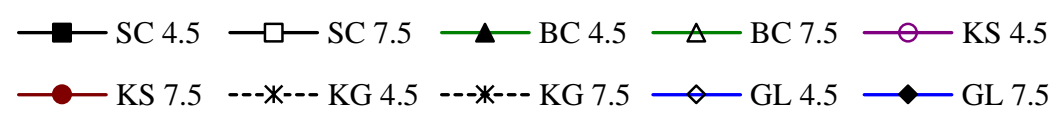

Figure 1. Growth pattern of five breed of sheep fed supplement containing defferent levels of undegradable protein

Table 4. Apparent digestibility (\%) of DM, CP, NDF, ADF and energy by five breed of sheeep fed on diet treatments

\begin{tabular}{lccccc}
\hline \hline \multirow{2}{*}{ Factors } & \multicolumn{5}{c}{ Parameter } \\
\cline { 2 - 6 } & DM & CP & NDF & ADF & Energy \\
\hline Breeds & n.s & n.s & n.s & n.s & n.s \\
BC & 51,65 & 75.62 & 44.0 & 37.78 & 62.04 \\
SC & 51,4 & 75.90 & 44.17 & 35.49 & 62.57 \\
CA & 53,44 & 71.78 & 45.32 & 38.53 & 62.66 \\
KG & 50,70 & 73.54 & 44.02 & 39.16 & 61.63 \\
GL & 53,38 & 78.64 & 44.84 & 37.49 & 65.26 \\
UDP levels & n.s & n.s & $*$ & n.s & n.s \\
4.5 & 52.18 & 76.21 & $41.97 \mathrm{~b}$ & 37.65 & 62.8 \\
7.5 & 52.05 & 73.98 & $46.96 \mathrm{a}$ & 37.73 & 62.84 \\
SEM & 2.0584 & 2.6636 & 3.3598 & 3.5099 & 2.0717 \\
\hline
\end{tabular}

$*=\mathrm{P} \leq 0.05 ; \mathrm{n} . \mathrm{s}=\mathrm{P} \geq 0.05$

Means followed by different letter in the same column indicate significantly different at $5 \%$

$\mathrm{BC}=$ Barbados Black Belly Cross

$\mathrm{CA}=$ Compass Agrinak

GL $=$ Local sheep breed (Local Garut)

$\mathrm{DM}=$ Dry matter

$\mathrm{KG}=$ Garut Composite

$\mathrm{SC}=$ St. Croix

$\mathrm{UDP}=$ Undegradable protein

$\mathrm{NDF}=$ Neutral detergent fiber

$\mathrm{CP}=$ Crude protein

$\mathrm{ADF}=$ Acid detergent fiber 
not significantly different among other breeds. On the other hand, at UDP 7.5\% OM digestibility was similar across breeds.

Table 5. Apparent OM digestibility (\%) of five breed of sheeep fed on diet treatments

\begin{tabular}{lcc}
\hline \hline \multirow{2}{*}{ Breeds } & \multicolumn{2}{c}{ UDP levels } \\
\cline { 2 - 3 } & 4.5 & 7.5 \\
\hline BC & $59.64^{\mathrm{ab}}$ & $61.78^{\mathrm{ab}}$ \\
$\mathrm{SC}$ & $63.62^{\mathrm{a}}$ & $62.0^{\mathrm{ab}}$ \\
$\mathrm{CA}$ & $65.22^{\mathrm{a}}$ & $59.83^{\mathrm{ab}}$ \\
KG & $57.81^{\mathrm{b}}$ & $61.13^{\mathrm{ab}}$ \\
GL & $61.21^{\mathrm{ab}}$ & $64.69^{\mathrm{a}}$ \\
\hline
\end{tabular}

Means followed by different letter in the same coloumn indicated significantly different at $5 \%$

UDP levels was not significant $(\mathrm{P}>0.05)$

$\mathrm{BC}=$ Barbados Black Belly Cross

$\mathrm{KG}=$ Garut Composite

$\mathrm{CA}=$ Compass Agrinak

$\mathrm{SC}=$ St. Croix

$\mathrm{GL}=$ Local sheep breed (Local Garut)

\section{DISCUSSION}

\section{Effect of breeds}

The total DMI of KG sheep was significantly highest than other breeds except for BC (Table 2). According to NRC (2006) DMI intake is affected by the demand for energy and the phisycal condition of the feed, these factors is related to body size at expected mature weight, and the maximum intake is achieved at $80 \%$ of mature weight. In the present study the age of all the sheep used in experiment was 11 months old with the initial body weight of each breed were 25.9; $21.5 ; 24.02 ; 23.3$ and $18.6 \mathrm{~kg}$ respectively for $\mathrm{BC}, \mathrm{SC}$, $\mathrm{CA}, \mathrm{KG}$ and GL. Current experiment all the sheep breed used was still in growth stage as indicated by linier pattern in growth of the sheep as shown in Figure 1. The BW of BC was the highest and followed by $\mathrm{CA}$ and $\mathrm{KG}$. However, when the DMI was converted into intake per $\mathrm{kg}$ body weight or per metabolic body weight $\left(\mathrm{kg} \mathrm{BW}^{0.75}\right) \mathrm{GL}$ has the highest intake. The ADG between KG and GL was similar and significantly higher than other breeds, therefore these breeds also had better feed conversion rasio (Table 3). Results of current study show that all the sheep had similar ability in digesting feed (Table 4), but their ability to deposit nutrients into body tissue were different as indicated by the different ADG of the sheep breed (Table 3). According to Orskov (1992) the rate of protein deposition in ruminants is affected by genetic. Wildeus et al. (2007) in their study compared three hair sheep breeds (Katahdin, Barbados Blackbelly and St Croix) fed on alfalfa hay ad libitum also reported that these sheep had different growth rate. The growth rate of Katahdin and St Croix was higher than Barbados Blackbelly. Simlarly Bunch et al. (2004) also reported that at similar diet quality (feed lot diet) the growth of lambs of wool sheep were higher than hair sheep.

When the ADG and DMI, was related to nutrient digestibility, it shows that $\mathrm{KG}$ and GL had similar genetic potensial and were better than other breeds. However, at the same age KG was better than GL in term of body size (body weight) (Table 3 ) this was due to $\mathrm{KG}$ sheep is considered as improved breed with higher growth rate and meat deposition potential than GL (Inounu et al. 2003). Results from present study was similar to the study reported by Inounu et al. (2003) who found that $\mathrm{KG}$ at 12 month old had higher body weight than GL. NRC (2006) sugessted that nutrient requirement of lambs at 8 months old with body weight $20 \mathrm{~kg}$ with expectation ADG $100 \mathrm{~g} / \mathrm{d}$, the sheep need RDP 71 g/day and UDP 64 g/day, and ME 1.98 Mcal/day. Whereas Kearl (1982) suggested total protein requirement for sheep at $20 \mathrm{~kg} \mathrm{BW}$ with targeted $\mathrm{ADG}$ of $100 \mathrm{~g} /$ day is $119 \mathrm{~g} /$ day or $12.58 \mathrm{~g} / \mathrm{kgBW}^{0.75}$. In the current study total protein consumption were in the ranges of $105.29-108.03 \mathrm{~g} /$ day or $8.84-10.6 \mathrm{~g} / \mathrm{kgBW}^{0.75}$ and energy consumption was $1.78 \mathrm{Mcal} /$ day. It shows that the CP intake in the present study was lower than Kearl (1982) and NRC (2006) suggestion this might be the reason that the growth rate was less than $100 \mathrm{~g} /$ day (ranges 57-86 g/day, Table 2). However, previously Yulistiani et al. (2011) reported that CA sheep at initial BW $16 \mathrm{~kg}$ although consumed protein $8.75 \mathrm{~g} / \mathrm{kgBW}^{0.75}$ which was lower than Kearl (1982) suggestion was able to produced ADG $100.2 \mathrm{~g} /$ day. The lower initial BW might caused the higher ADG in previous study (Yulistiani et al. 2011) than in current study. The growth of $\mathrm{BC}$ and $\mathrm{CS}$ in this study was relatively comparable, results of this study was similar to the study reported by Subandriyo et al. (2000) who reported that the body weight of $\mathrm{BC}$ and $\mathrm{CA}$ was comparable from 4 to 9 months of age. Moreover, Handiwirawan et al. (2012) studied the five breeds which were similar breeds used in the current study reared in communal pen, and observed that the growth of composite breed (KS, KG, SC and BC) at 3-7 months old was comparable, while growth of LG was the lowest.

\section{Effect of UDP levels}

The DMI, ADG and feed conversion was not affected by UDP levels (Table 2 and Table 3) with the average of DMI, ADG and FCR were $884.5 \mathrm{~g} /$ day, $73.24 \mathrm{~g} /$ day and 12.65 respectively. The increasing UDP levels is expected to increase body tissue deposition through increasing ADG, however this was not occurred. This results were consistent with previous 
study reported by Can et al. (2004) who increased UDP levels from 3.36 to $5.01 \%$ through inclusion of fish meal in concentrate which contained $16 \% \mathrm{CP}$. The concentrate was fed ad libitum plus $100 \mathrm{~g} /$ day of grass hay to Awasi lambs, the results showed that the ADG, DMI and feed eficiency were not affected by UDP levels. Moreover Can et al. (2004) stated that UDP levels at $3.4 \%$ in the diet was sufficient to meet requirement for protein deposition of 3-4 months old of Awasi lambs. Similarly, Tufarelli et al. (2009) reported that no effect of ratio between UDP and RDP of the diet contained equal CP on DMI and body weight gain of Comissana ewe lambs. Wagner et al. (2009) suggested that $62 \%$ of $\mathrm{CP}$ in the form of RDP in diet containing $13.5 \%$ crude protein was required for finishing crossbred yearling steer. In current study, with assumption that elephant grass contained 50\% RDP, therefore, calculated UDP content in the diet (grass + concentrate) was $3.9 \%$ of CP content (ratio UDP:RDP = $33.87: 66.13 \%$ ) of $\mathrm{CP}$ intake at UDP $4.5 \%$ diet treatment. Whereas in treatment UDP 7.5 the ratio UDP: RDP was 46.3:53.7\%. It shows that RDP in this study was higher at UDP 4.6 and lower at UDP 7.5 than Wagner et al. (2009) suggestion. However nutriens digestibility were not affected by level UDP in the diet except for OM and NDF (Table 4). Chalupa (1975) suggested that in growing young ruminants, UDP is potential to improve gain when protein from microbial supply was insufficient to meet the requirement of amino acid for maintenance and rapid growth of ruminants. In iso protein diet, the increase of UDP caused the decreased of RDP availability which needed or improving nutrient digestibility and optimum microbial protein synthesis. The non significant effect of increased UDP level from 4.5 into $7.5 \%$ on the ADG of the lambs in current study suggested that protein microbial supply from both diet was sufficient to meet requirement for maintenance and rapid growth of lambs in all breeds.

Nutrients digestibility were not affected by level of UDP in the concentrate (Table 4). Tufarelli et al. (2009) reported that different levels of UDP in the diet did not affect DM, OM, CF, and ADF and cellulose. Similarly Atkinson et al. (2007) also observed no effect of DM and OM digestibility due to increasing UDP in the diet, but increasing UDP levels quadratically increased NDF digestibility, this means that at certain point further increased of UDP content was not able to increase NDF digestibility. In current study the NDF digestibility in UDP 7.5 was higher than 4.6 this might be caused by the release of ammonia from RDP was match with energy availability and resulted in higher microbial protein synthesis lead to the higher NDF digestibility. Chandrasekharaiah et al. (2012) reported that supplementation of $16 \mathrm{~g} \mathrm{RDN} / \mathrm{kg}$ DOMI was adequate for optimum microbial protein synthesis and for improving nutrient digestibility of Bandur sheep fed on low quality basal diet (finger millet straw). They observed that further increase of RDN caused the exses of RDN than required for improving digestibility. Consequently, the release of ruminal ammonia from RDN degradation did not match the rate of organic matter degradation of straw. In the current study the RDN intake was $23.68 \mathrm{~g} / \mathrm{kg}$ DOMI, in UDP $4.5 \%$ and $19.19 \mathrm{~g} / \mathrm{kg}$ DOMI in UDP $7.5 \%$, it shows that this RDN intake was higher than Chandrasekharaiah et al. (2012) suggestion. The basal diet in the current study was elephant grass with higher nutritive value than finger millet straw, it was expected that the digestibility of organic matter of the grass able to meet the excess of ammonia release from the protein degradation of the diet. However the energy from organic matter digestibility was not able to meet the excess of ammonia this condition might be caused by the lower energy metabolis intake of the diet which was 1.781 Mcal could not match the available ammonia in the rumen.

\section{CONCLUSION}

The response of five breeds of sheep to dietary treatment was not different on growth rate with similar ability in digesting the nutrients. The increasing of UDP levels from 4.5 to $7.5 \%$ in concentrate diet did not improve the growth performance of sheep. The growth rate of five breeds of sheep was affected by breed.

\section{REFERENCES}

[AOAC] Association of Official Analytical Chemist. 1990. Official method of analysis. 12th ed. Washington DC (US): Association of Official Analytical Chemist.

Atkinson RL, Toone CD, Robinson TJ, Harmon DL, Ludden PA. 2007. Effects of supplemental ruminally degradable protein versus increasing amounts of supplemental ruminally undegradable protein on nitrogen retention, apparent digestibility, and nutrient flux across visceral tissues in lambs fed low-quality forage. J Anim Sci. 85:3331-3339.

Bunch TD, Evans RC, Wang S, Brennand CP, Whittier DR, Taylor BJ. 2004. Feed efficiency, growth rates, carcass evaluation, cholesterol level and sensory evaluation of lambs of various hairand wool sheep and their crosses. Small Rumin Res. 52:239-245.

Can A, Denek N, Tufenk S, 2004. Effect of escape protein level on finishing performance of Awassi lambs. Small Rumin Res. 55:215-219.

Chalupa W. 1975. Rumen bypass and protection of proteins and amino acids. J Dairy Sci. 68:1198-1218. 
Chandrasekharaiah M, Thulasi A, Sampath KT. 2012. Effect of different rumen degradable nitrogen levels on microbial protein synthesis and digestibility in sheep fed on finger millet straw (Eleucine coracana) based diet. Small Rumin Res. 102:151-156.

Garg MR. 1998. Role of Bypass protein in feeding ruminants on crop residues based diet: Review. AJAS. 11:107-116.

Handiwirawan E, Noor RR, Sumantri C, Subandriyo. 2012. Hubungan tingkah laku dengan sifat-sifat produksi dari lima bangsa domba. JITV. 17:179-188.

Inounu I, Hidayati, Subandriyo, Tiesnamurti B, Nafiu O. 2003. Analisis keunggulan relatif domba Garut anak dan persilangannya. JITV. 8:170-182.

Kearl LC. 1982. Nutrient requirements of ruminants in developing countries. Utah State University (USA): International Feestuff Institute, Utah Agricultural Experiment Station.

McDonald P, Edwards RA, Greenhalgh JFD, Morgan CA. 2002. Animal nutrition. 6th ed. Harlow (UK): Pearson Education Limited.

[NRC] National Research Council. 2006. Nutrient requirement of small ruminants. Washington DC (US): National Academic Press.

Ørskov ER. 1992. Protein nutrition in ruminants. 2nd ed. London (UK): Academic Press.

[SAS] Statistics Analysis System. 2009. Base SAS 9.2 procedures guide, statistical procedures. North Carolina (US): SAS Institute Inc., Cary.

Subandriyo, Setiadi B, Handiwirawan E, Suparyanto A. 2000. Performa domba komposit hasil persilangan antara domba lokal sumatera dengan domba rambut pada kondisi dikandangkan. JITV. 6:1-11.

Tufarelli V, Dario M, Laudadio V. 2009. Influence of dietary nitrogen sources with different ruminal degradability on growth performance of Comisana ewe lambs. Small Rumin Res. 81:132-136.

Van Soest PJ, Robertson JB, Lewis BA. 1991. Methods for dietary fiber, neutral detergent fiber and non-starch polysaccharides in relation to animal nutrition. J Dairy Sci. 74:3583-3593.

Wagner JJ, Engle TE. Bryant TC. 2009. The effect of rumen degradable and rumen undegradable intake protein on feedlot performance and carcass merit in heavy yearling steers. J Anim Sci. 88:1073-1081.

Wildeus S, Turner KE, Collins JR. 2007. Growth, intake, diet digestibility, and nitrogen use in three hair sheep breeds fed alfalfa hay. Small Rumin Res. 69:221-227

Yulistiani D, Mathius I-W, Puastuti W. 2011. Bungkil kedelai terproteksi tannin cairan batang pisang dalam pakan domba sedang tumbuh. JITV. 16:33-40.

Yulistiani D, Puastuti W, Priyanto D. 2014. Pertumbuhan domba hasil persilangan dengan manajemen pemberian pakan di pedesaan. Pamungkas D, Widiawati Y, Susan MP, Purwantari ND, Widiastuti R, Brahmantiyo B, Herawati T, Kusumaningsih A, Handiwirawan E, Puastuti W, penyunting. Prosiding Seminar Nasional Peternakan dan Veteriner. Bogor (Indones): Pusat Penelitian dan Pengembangan Peternakan. hlm. 461-467. 